\title{
Genetic Variability and Character Association in Sesame (Sesamum indicum L.) Genotypes
}

\author{
Atul Singh*, Rajani Bisen and Akanksha Tiwari \\ Project Coordinating Unit (Sesame and Niger), Jawaharlal Nehru Krishi Vishwa Vidyalaya, \\ Jabalpur, India \\ *Corresponding author
}

\begin{abstract}
A B S T R A C T
The study was carried out to assess the genetic variability and association of traits with respect to seed yield and its components in sesame genotypes. Seventy five sesame genotypes were grown during kharif 2016 at the Project Coordinating Unit Sesame and Niger, JNKVV, Jabalpur for the estimation of phenotypic and genotypic variances, heritability, genetic advances, correlation and path coefficient analysis for seed yield and yield related traits. High values for phenotypic coefficient of variation (PCV) and genotypic coefficient of variation (GCV) was recorded for traits viz., number of secondary branches/plant followed by number of primary branches/plant, seed yield/plant, number of seeds/capsule, number of capsules/plant, transpiration rate, stomatal conductance, photosynthetic rate, chlorophyll content and days to flower initiation and hence improvement through selection of these traits could be possible. High heritability coupled with moderate genetic advance was recorded for oil content and days to $50 \%$ flowering. Thus, these traits are most likely controlled by additive gene action which is very useful in selection. Correlation and path analysis revealed that the characters viz., plant height, number of secondary branches/plant, number of seeds/capsule and oil content have positive direct association along with significant positive correlation with seed yield. Therefore, these characters can be considered as a criterion for improving seed yield in breeding programs of sesame.
\end{abstract}

\section{Keywords}

Sesame, Heritability,

Correlation, Path

analysis, Additive gene action, Selection

Article Info

Accepted:

18 October 2018

Available Online:

10 November 2018

\section{Introduction}

Sesame (Sesamum indicum L.) known as 'benni seed', 'gingelly', 'simsim', 'til' etc., is an important and perhaps the oldest and ancient oilseed crops known to man. It is cultivated extensively from tropical regions to the temperate zones in the world. It is fifth important edible oil crop in India after groundnut, rapeseed-mustard, sunflower and soybean. Sesame seed contains $50 \%$ oil, $23 \%$ protein and $15 \%$ carbohydrate (Ranganatha et al., 2012). Sesame seed oil has long shelf life due to the presence of lignans (sesamin, sesamol, sesamolin), which have remarkable antioxidant function, resisting oxidation. It can set seed and yield well under fairly high temperature and can grow in stored soil moisture without rainfall and irrigation. However, continuous flooding or severe drought adversely affects the crop resulting in low yield. 
Genetic variation survives for agronomically vital characters in sesame but its production is still very low in India. Traditional sesame landraces as well as related wild species are an important source of genetic diversity for breeders and form the backbone of agricultural production. Selection for high yielding types with wider adaptability shall help in increasing the production both locally and globally. But the performance of crop is affected by such factors as climatic, nutrients, water availability, inter and intra specific competitions, pest and diseases, as well as socio-cultural and socioeconomic factors. The knowledge of genetic variability in germplasm will help in the selection and breeding of high yielding, good quality cultivars that will increase production. It is necessary to study variability in respect of quantitative characters with reference to genetic parameters such as genotypic and, phenotypic variances, heritability (broad sense) and genetic advance.

Understanding of relationship between yield and its components is fundamental for selection process and its relationship can be explained by means of correlation and path coefficient analysis. Correlation analysis is used to understand the relationships existing between yield and yield components. However, correlation alone does not provide the exact knowledge and contribution made by the yield attributes. Path coefficient analysis has been suggested to separate correlation coefficient into direct and indirect effects. In sesame, path analysis has used to identify traits that have significant effects on seed yield

\section{Materials and Methods}

The present experiment was conducted under Project Coordinating Unit (Sesame and Niger) Research Farm, JNKVV, Jabalpur (M.P.) during kharif 2016. The soil of the experimental area is medium black with uniform topography and free from water logged conditions. Jabalpur has sub-tropical and semi-arid climate. The main features are hot and dry summer and cold winter with occasional showers. The experimental material consisted of 75 sesame genotypes laid out in a Randomized Block Design replicated thrice. The distance between rows was maintained at $0.30 \mathrm{~m}$ and plant to plant 0.10 $\mathrm{m}$. The crop was raised under recommended package of practices along with prophylactic protection measures. The observations were recorded on days to flower initiation, days to $50 \%$ flowering, plant height $(\mathrm{cm})$, number of primary branches/plant, number of secondary branches/plant, number of capsules/plant, capsule length $(\mathrm{cm})$, days to maturity, number of seeds/capsule, 1000 seed weight (g), seed yield/plant ( $\mathrm{g}$ ) and oil content $(\%)$. The data were subjected to statistical analysis

\section{Statistical analysis}

Mean values of the characters for each genotype per replication were used for analysis of variance as per (Cochran and Cox, 1950). Heritability estimates were calculated according to (Hanson, 1956) and genetic advance according to (Johnson, 1955). Genotypic and phenotypic correlation coefficients were calculated according to the formula suggested by (Miller et al., 1958). Path coefficients were estimated by following (Dewey and Lu, 1959). The estimates of correlation coefficient and path coefficient analysis were calculated by analyzing data using INDOSTAT statistical package.

\section{Results and Discussion}

The analysis of variance revealed significant difference among the genotypes for all traits viz., days to flower initiation, days to $50 \%$ flowering, plant height, number of primary branches/plant, number of secondary branches/plant, number of capsules/plant, 
capsule length, days to maturity, number of seeds/capsule, 1000 seed weight, oil content $(\%)$, leaf area index, photosynthetic rate, chlorophyll content, stomatal conductance, transpiration rate, water use efficiency and seed yield/plant, indicating the presence of sufficient variability among the evaluated genotype for the traits under consideration. This indicates that sufficient variability is present for most of the important characters among different genotypes. Similar results have been reported by Shekhawat et al., (2013) for days to flowering, plant height, capsule bearing length, capsules/plant, capsule length, seed yield/plant, days to maturity and oil content; Sabiel et al., (2015) for plant height, flowering time and days to maturity.

Examination of the components of variance revealed that the phenotypic coefficients of variation (PCV) was higher than the corresponding genotypic coefficients of variation $(\mathrm{GCV})$ for all the characters with a narrow difference indicates that environmental influence was least and preponderance of genetic factors controlling variability in these traits. High magnitude of PCV and GCV were observed for the traits viz., number of secondary branches/plant followed by number of primary branches/plant, seed yield/plant, number of seeds/capsule, number of capsules/plant, transpiration rate, stomatal conductance, photosynthetic rate, chlorophyll content and days to flower initiation. Results indicated greater scope for selection of these traits for further breeding work. Similar results have been reported by Sekhawat et al., (2013), Gangadhara et al., (2012) and Parameshwarappa et al., (2009) for seed yield/plant; Aristya et al., (2017), Saxena et al., (2016), Desawi et al., (2014) for number of capsules/plant; Mustafa et al., (2015), Rani (2014) for number of primary branches/plant and number of secondary branches/plant; Narayan and Murugan (2013) for number of seeds/capsule. Moderate values of PCV were noticed for characters viz., days to $50 \%$ flowering, plant height, water use efficiency and oil content (\%). Similar results have been recorded by Vanishree et al., (2013) and Gidey et al., (2013) for days to $50 \%$ flowering. Low values of PCV were noticed for capsule length, 1000 seed weight and days to maturity. Similar results have been reported by Sekhawat et al., (2013) and Vanishree et al., (2013), respectively.

However, high GCV value alone is not sufficient for the determination of the extent of genetic advance to be expected by selection. Burton (1952) suggested that GCV together with heritability estimates would give the best picture of the extent of the advance to be expected by selection.

The highest value of heritability was noted in chlorophyll content followed by leaf area index, days to flower initiation, numbers of capsules/plant. Hence these traits might be governed by additive genes indicating that direct selection would be effective from present genotypes. Similar results have been reported by Vanishree et al., (2013), Shekhawat et al., (2013), Kumhar et al., (2013), Gangadhara et al., (2012) for number of capsules/plant.

Heritability estimates would be reliable if accompanied by a high estimated genetic advance. High heritability coupled with moderate genetic advance was recorded for oil content and days to $50 \%$ flowering. THus these traits are most likely controlled by additive gene action which is very useful in selection. Similar results were reported by Gangadhara et al., (2012), Gidey et al., (2012), Tripathi et al., (2013) and Abate and Mekbib (2015) for days to 50\% flowering. Moderate heritability coupled with high genetic advance was recorded for stomatal conductance, number of primary branches/plant and seed yield/ plant (Table 14). 
Table.3 Phenotypic and Genotypic correlation analysis for yield and yield related traits in sesame genotypes

\begin{tabular}{|c|c|c|c|c|c|c|c|c|c|c|c|c|c|}
\hline Character & & $\begin{array}{l}\text { Days to } \\
\text { flower- } \\
\text { initiation }\end{array}$ & $\begin{array}{l}\text { Days to } \\
\mathbf{5 0 \%} \\
\text { flowering }\end{array}$ & $\begin{array}{l}\text { Plant } \\
\text { height }\end{array}$ & $\begin{array}{c}\text { Number } \\
\text { of } \\
\text { primary } \\
\text { branches/ } \\
\text { plant }\end{array}$ & $\begin{array}{c}\text { Number of } \\
\text { secondary } \\
\text { branches/plant }\end{array}$ & $\begin{array}{c}\text { Number of } \\
\text { capsules/plant }\end{array}$ & $\begin{array}{l}\text { Capsule } \\
\text { length }\end{array}$ & $\begin{array}{l}\text { Days to } \\
\text { maturity }\end{array}$ & $\begin{array}{l}\text { Number } \\
\text { of seeds } \\
\text { /capsule }\end{array}$ & $\begin{array}{c}1000 \\
\text { seed } \\
\text { weight }\end{array}$ & $\begin{array}{c}\text { Oil } \\
\text { content }\end{array}$ & $\begin{array}{c}\text { Seed } \\
\text { yield/plant }\end{array}$ \\
\hline \multirow{2}{*}{$\begin{array}{l}\text { Days to } \\
\text { flower } \\
\text { initiation }\end{array}$} & $\mathbf{P}$ & 1.0000 & $0.9786 * *$ & -0.0928 & 0.0706 & -0.1032 & -0.0566 & 0.0350 & $0.6565 * *$ & -0.0455 & 0.1217 & 0.0312 & $-0.2406 * *$ \\
\hline & $\mathbf{G}$ & 1.0000 & 0.9932 & -0.1123 & 0.0620 & -0.1660 & -0.0691 & 0.0185 & 1.0363 & -0.0640 & 0.2059 & 0.0150 & -0.3596 \\
\hline \multirow{2}{*}{$\begin{array}{l}\text { Days to } \mathbf{5 0 \%} \\
\text { flowering }\end{array}$} & $\mathbf{P}$ & & 1.0000 & -0.1111 & 0.0579 & -0.1234 & -0.0733 & 0.0535 & $0.6837 * *$ & -0.0366 & $0.1462 *$ & 0.0237 & $-0.2387 * *$ \\
\hline & $\mathbf{G}$ & & 1.0000 & -0.1241 & 0.0471 & -0.2068 & -0.0848 & 0.0265 & 1.0513 & -0.0438 & 0.1961 & 0.0045 & -0.3707 \\
\hline \multirow[t]{2}{*}{ Plant height } & $\mathbf{P}$ & & & 1.0000 & -0.352 & 0.0677 & $0.4025^{* *}$ & $0.1695 *$ & -0.081 & 0.0496 & 0.0298 & -0.0143 & $0.2159 * *$ \\
\hline & $\mathbf{G}$ & & & 1.0000 & -0.0348 & 0.1011 & 0.4943 & 0.2522 & -0.1686 & 0.3029 & 0.0838 & 0.0453 & 0.4758 \\
\hline \multirow{2}{*}{$\begin{array}{l}\text { Number of } \\
\text { primary } \\
\text { branches/ } \\
\text { plant }\end{array}$} & $\mathbf{P}$ & & & & 1.0000 & $0.4082 * *$ & 0.0391 & 0.0564 & 0.0244 & 0.0174 & -0.0993 & 0.1207 & -0.0723 \\
\hline & $\mathbf{G}$ & & & & 1.0000 & 0.4492 & 0.0296 & 0.1002 & 0.1613 & -0.0009 & -0.2006 & 0.1307 & -0.1780 \\
\hline \multirow{2}{*}{$\begin{array}{l}\text { Number of } \\
\text { secondary } \\
\text { branches/ } \\
\text { plant }\end{array}$} & $\mathbf{P}$ & & & & & 1.0000 & 0.1194 & $-0.1429 *$ & -0.0508 & $0.1595^{*}$ & -0.1068 & $0.2374 * *$ & $0.1558 *$ \\
\hline & G & & & & & 1.0000 & 0.1420 & -0.2887 & -0.0608 & 0.2895 & -0.2293 & 0.3483 & 0.2056 \\
\hline \multirow{2}{*}{$\begin{array}{l}\text { Number of } \\
\text { capsules/ } \\
\text { plant }\end{array}$} & $\mathbf{P}$ & & & & & & 1.0000 & 0.0645 & -0.0663 & 0.1072 & $0.1958 * *$ & 0.1036 & $0.2701 * *$ \\
\hline & $\mathbf{G}$ & & & & & & 1.0000 & 0.2549 & -0.1646 & 0.2460 & 0.3138 & 0.1255 & 0.2898 \\
\hline \multirow{2}{*}{$\begin{array}{l}\text { Capsule } \\
\text { length }\end{array}$} & $\mathbf{P}$ & & & & & & & 1.0000 & 0.0634 & -0.1183 & 0.0760 & -0.0512 & 0.1212 \\
\hline & $\mathbf{G}$ & & & & & & & 1.0000 & -0.0150 & -0.242 & 0.2809 & -0.1027 & 0.4936 \\
\hline \multirow{2}{*}{$\begin{array}{l}\text { Days to } \\
\text { maturity }\end{array}$} & $\mathbf{P}$ & & & & & & & & 1.0000 & 0.0381 & $0.1809 * *$ & 0.0322 & $-0.1721 * *$ \\
\hline & $\mathbf{G}$ & & & & & & & & 1.0000 & -0.1245 & 0.1268 & 0.0346 & -0.3746 \\
\hline \multirow{2}{*}{$\begin{array}{l}\text { Number of } \\
\text { seeds/capsule }\end{array}$} & $\mathbf{P}$ & & & & & & & & & 1.0000 & -0.0574 & $0.1663 *$ & $0.2748 * *$ \\
\hline & $\mathbf{G}$ & & & & & & & & & 1.0000 & -0.2846 & 0.3558 & 0.3192 \\
\hline \multirow{2}{*}{$\begin{array}{l}1000 \text { seed } \\
\text { weight }\end{array}$} & $\mathbf{P}$ & & & & & & & & & & 1.0000 & 0.0664 & -0.0258 \\
\hline & $\mathbf{G}$ & & & & & & & & & & 1.0000 & 0.0800 & -0.1031 \\
\hline \multirow{2}{*}{$\begin{array}{l}\text { Oil content } \\
\%\end{array}$} & $\mathbf{P}$ & & & & & & & & & & & 1.0000 & $0.2655^{* *}$ \\
\hline & $\mathbf{G}$ & & & & & & & & & & & 1.0000 & 0.3651 \\
\hline
\end{tabular}

Significant label 0.050 .01

If correlation $\mathrm{r}=0.13080 .1714$ 
Table.4 Genotypic and Phenotypic path coefficient analysis showing direct and indirect effects for yield and yield related traits in sesame genotypes

\begin{tabular}{|c|c|c|c|c|c|c|c|c|c|c|c|c|c|}
\hline Character & & $\begin{array}{l}\text { Days to } \\
\text { flower } \\
\text { initiation }\end{array}$ & $\begin{array}{l}\text { Days to } \\
50 \% \\
\text { flowering }\end{array}$ & $\begin{array}{l}\text { Plant } \\
\text { height }\end{array}$ & $\begin{array}{c}\text { Number } \\
\text { of } \\
\text { primary } \\
\text { branches/ } \\
\text { plant }\end{array}$ & $\begin{array}{c}\text { Number. } \\
\text { of } \\
\text { secondary } \\
\text { branches/ } \\
\text { plant }\end{array}$ & $\begin{array}{l}\begin{array}{c}\text { Number } \\
\text { of }\end{array} \\
\text { capsules/ } \\
\text { plant }\end{array}$ & $\begin{array}{l}\text { Capsule } \\
\text { length }\end{array}$ & $\begin{array}{l}\text { Days to } \\
\text { maturity }\end{array}$ & $\begin{array}{l}\text { Number } \\
\text { of seeds } \\
\text { /capsule }\end{array}$ & $\begin{array}{c}1000 \text { seed } \\
\text { weight }\end{array}$ & $\begin{array}{c}\text { Oil } \\
\text { content } \\
(\%)\end{array}$ & $\begin{array}{c}\text { Seed yield/ } \\
\text { plant }\end{array}$ \\
\hline \multirow{2}{*}{$\begin{array}{c}\text { Days to flower } \\
\text { initiation }\end{array}$} & $\mathrm{P}$ & -0.2206 & -0.2159 & 0.0205 & -0.0156 & 0.0228 & & & -0.1448 & & & -0.0069 & -0.2406 \\
\hline & G & 0.4507 & 0.4476 & -0.0506 & 0.0280 & -0.0748 & & & & -0.0288 & & 0.0068 & 3596 \\
\hline \multirow{2}{*}{$\begin{array}{c}\text { Days to } 50 \% \\
\text { flowering }\end{array}$} & $\mathrm{P}$ & 0.0605 & 0.0619 & -0.0069 & 0.0036 & -0.0076 & & & & 0023 & & 0.0015 & 387 \\
\hline & G & -0.4112 & -0.4140 & 0.0514 & -0.0195 & & & & & & & -0.0019 & 707 \\
\hline \multirow[t]{2}{*}{ Plant height } & $\mathrm{P}$ & -0.0076 & -0.0091 & & -0.0029 & & & & & & & -0.0012 & \\
\hline & $\mathrm{G}$ & -0.0210 & -0.0232 & 0.1872 & -0.0065 & & & & & & & 0.0085 & \\
\hline \multirow{2}{*}{$\begin{array}{c}\text { Number of primary } \\
\text { branches/plant }\end{array}$} & $\mathrm{P}$ & -0.0107 & -0.0087 & 0.0053 & & & & & & 926 & & -0.0182 & 723 \\
\hline & G & -0.0312 & -0.0237 & 0.0175 & & & & & & & & -0.0658 & 780 \\
\hline \multirow{2}{*}{$\begin{array}{c}\text { Number of } \\
\text { secondary } \\
\text { branches/plant } \\
\end{array}$} & $\mathrm{P}$ & & & & & & & & & & & & \\
\hline & G & -0.0649 & -0.0809 & 0.0395 & 0.1756 & 0.3910 & 0.0555 & -0.1129 & -0.0238 & 0.1132 & -0.0897 & 0.1362 & 0.2056 \\
\hline \multirow{2}{*}{$\begin{array}{c}\text { Number of } \\
\text { capsules/plant }\end{array}$} & $\mathrm{P}$ & -0.0097 & -0.0126 & 0.0693 & 0.0067 & 0.0206 & 0.1721 & & & & & 0.0178 & 0.2701 \\
\hline & $\mathrm{G}$ & 0.0042 & 0.0051 & -0.030 & & -0.0086 & & & & & 0190 & -0.0076 & 898 \\
\hline \multirow[t]{2}{*}{ Capsule length } & $\mathrm{P}$ & 0.0059 & 0.0090 & & & & & & & & & -0.0086 & \\
\hline & G & 0.0144 & 0.0206 & 0.1957 & 0.0778 & -0.2241 & 0.1978 & 0.7761 & -0.0117 & -0.1878 & 0.2180 & -0.0797 & .4936 \\
\hline \multirow[t]{2}{*}{ Days to maturity } & $\mathrm{P}$ & -0.0388 & -0.0404 & 0.0048 & -0.0014 & 030 & 0.0039 & -0.0037 & 0591 & -0.0023 & -0.0107 & -0.0019 & 1721 \\
\hline & G & -0.2351 & & & & & & & & & & -0.0079 & 3746 \\
\hline \multirow{2}{*}{$\begin{array}{c}\text { Number of } \\
\text { seeds/capsule } \\
\end{array}$} & $\mathrm{P}$ & -0.0096 & -0.0078 & 0.0105 & & & & & & & -0.0122 & 0.0353 & 0.2748 \\
\hline & $\mathrm{G}$ & -0.0076 & -0.0052 & 0.0361 & -0.0001 & 0.0345 & 0.0293 & -0.0289 & -0.0148 & 0.1193 & -0.0339 & 0.0424 & 0.3192 \\
\hline \multirow[t]{2}{*}{1000 seed weight } & $\mathrm{P}$ & -0.0065 & -0.0078 & -0.0016 & 0.0053 & 0.0057 & -0.0104 & -0.0040 & -0.0096 & 0.0030 & 0530 & -0.0035 & -0.0258 \\
\hline & G & -0.0631 & -0.0601 & & & & & & & & & -0.0245 & -0.1031 \\
\hline \multirow[t]{2}{*}{ Oil content (\%) } & $\mathrm{P}$ & 0.0071 & 0.0054 & -0.0032 & 0.0274 & 0.0538 & 0.0235 & -0.0116 & 0.0073 & 0.0377 & 0.0151 & 0.2266 & 0.2665 \\
\hline & G & 0.0054 & 0.0016 & 0.0163 & 0.0469 & 0.1249 & 0.0450 & -0.0368 & 0.0124 & 0.1276 & 0.0287 & 0.3586 & 0.3651 \\
\hline
\end{tabular}

R Square $=0.9016$

Residual effect $=0.3137$

Note: Diagonal bold figure are the directs effect and the off diagonal are Indirect effects. 
Moderate heritability coupled with moderate genetic advance was recorded for transpiration rate, plant height and photosynthetic rate. Similar results have been reported by Tripathi et al., (2013) for plant height; Low heritability coupled with high genetic advance was recorded for number secondary branches/plant. Low heritability coupled with low genetic advance was recorded for 1000 seed weight, days to maturity, capsule length, number of seeds/capsule and water use efficiency. Similar results have been reported by Shekhawat et al., (2013) for 1000 seed weight and capsule length; Abate and Mekbib (2015) for days to maturity and number of seeds/capsule.

Phenotypic correlation coefficient was estimated in all character combinations with the objective to get information about the nature, extent and direction of selection pressure to achieve practical and usable results. In general, genotypic correlation coefficients were higher in magnitude than the phenotypic correlation coefficient. This indicated that although there is strong inherent association between the various pairs of characters studied the low phenotypic correlation would result from the masking and modifying effects of environment on the association of characters at gene level. Shekhawat et al., (2013) also reported that genotypic correlation coefficients were higher than the respective phenotypic correlation coefficients for all the characters.

Study revealed that seed yield/plant showed highly positive significant correlation with number of seeds/capsule followed by number of capsules /plant, oil content, plant height and number of secondary branches/plant. Similar results were reported by Fazal et al., (2015), Bharathi et al., (2015), Abate and Mekbib (2015) for number of seeds/capsule; Bharathi et al., (2015), Fazal et al., (2015),
Ismaila and Usman (2014) for number of capsules/plant. The association analysis revealed that plant height, number of primary branches/ plant, number of capsules/plant and 1000 seed weight were the important characters and may be selected to increase the seed yield. Present findings also revealed that by making selection for a particular character, simultaneous improvement in the associated character may be achieved.

Path coefficient analysis was carried out using genotypic and phenotypic correlation coefficients and revealed that substantial positive direct effect on seed yield was exerted by capsule length, days to flower initiation, number of secondary branches/plant, oil content, plant height and number of seeds/ capsule. Therefore, these traits may be considered as the principal traits while selecting for seed yield. Selection indices may be formed by considering all these characters for improvement of seed yield. Similar results have been reported by Vanishree et al., (2013) for capsule length; Abate and Mekbib (2015) and Shekhawat et al., (2013) for plant height; Saxena and Bisen (2016) for number of branches/plant; Fazal et al., (2015) and Bharathi et al., (2015) for number of seeds/capsule.

Thus, on the basis of above study the characters viz., plant height, number of secondary branches/plant, number of seeds/capsule and oil content have positive direct association along with significant positive correlation with seed yield. Therefore, these characters can be considered as a criterion for improving seed yield in breeding programs of sesame.

\section{References}

Abate M and Mekbib F. 2015. Assesment of genetic variability and character association in Ethopian low-altitude 
sesame (Sesamum indicum L.) genotypes. Journal of Advanced Studies in Agricultural, Biological and Environmental Sciences (JABE) 2(3): 55-66.

Aristya VE, Taryono and Wulandari. 2017. Genetic variability, standardized multiple linear regression and principal component analysis to determine some important sesame yield components AGRIVITA Journal of Agricultural Science. 39(1): 83-90.

Bharathi D, Rao VT Venkanna, V Bhadru D. 2015. Association analysis in sesame (Sesamum indicum L.). International Journal of Applied Biology and Pharmaceutical Technology 6 (1): 209212.

Burton GW. 1952. Quantitative inheritance in grasses. Proceedings of $6^{\text {th }}$ International Grassland Congress 1: 273-283.

Cochran GW and Cox GM.1950. Experimental Designs. John Wiley and Sons New York, NY.

Desawi HT, Sentayehu AK, and Daniel EG. 2014. Assessment of genetic variability, genetic advance, correlation and path analysis for morphological traits in sesame genotypes. Asian Journal of Agricultural Research 8(4): 181-197.

Dewey DR and Lu KH. 1959. Correlation and path coefficient analysis of components of crested wheat grass seed production. Agronomy Journal 51: 515-518.

Fazal A, Mustafa HSB Hasan EU Anwar M Tahir MHN and Sadaqat HA.2015. Interrelationship and path coefficient analysis among yield and yield related traits in sesame (Sesamum indicum L.) Nature and Science. 13(5): 27-32.

Gangadhara K, Chandra P, Bharamaraj B, Shadakshari TV, Yathish KR and Rajesh AM. 2012. Genetic divergence, genetic advance and heritability in sesame (Sesamum indicum L.). Bioinfolet 9 (4): 457-462.
Gidey YT, Kebede SA and Gashawbeza GT. 2013. Assessment of genetic variability, genetic advance, correlation and path analysis for morphological traits in sesame genotypes. International Journal of Plant Breeding and Genetics 7 (1): 21-34.

Hanson CH, Robinson HF and Comstock RE. 1956. Biometrical studies of yield in segregating population of Korean Lespecteza. Agronomy Journal 46 (6): 268-272.

Ismaila A and Usman A. 2014. Genetic variability for yield and yield components in sesame (Sesamum indicum L.). International Journal of Science and Research 3(9): 63-66.

Johnson HW, Robinson HF and Comstock RE. 1955. Genotypic, phenotypic correlations in soybean and their implication in selection. Agronomy Journal 47: 477- 483.

Kumhar SR and Solanki ZS. 2009. Genetic diversity and variability in sesame (Sesamum indicum L.). Journal of Oilseeds Research (26): 162-164.

Miller D A, Williams JC, Robinson HF and Comstock KB. 1958. Estimates of genotypic and environmental variances and co variances in upland cotton and their implication in selection. Agronomy Journal 50: 126-131.

Mustafa HSB, Hasan EU, Qurban Ali Q, Anwar M, Aftab $\mathrm{M}$ and Mahmood T. 2015. Selection criteria for improvement in sesame (Sesamum indicum L.). American Journal of Experimental Agriculture 9(4): 1-13.

Narayan R and Murgan S. 2013. Studies on variability in sesame (Sesamum indicum L.). International Journal of Agricultural Research 2 (11): 52-55.

Parameshwarappa SG, Palakshappa MG, Salimath PM and Parameshwarappa KG. 2009. Studies on genetic variability and character association in germplasm 
collection of sesame (Sesamum indicum L.). Karnataka Journal of Agriculture Sciences 22 (2): 252-254

Ranganatha ARG, Lokesha R, Tripathi A, Tabassum Aasfa, Paroha $\mathrm{S}$ and Shrivastava MK. 2012. Sesame improvement-Present status and future strategies. Journal of Oilseeds Research 29 (1): 1-26.

Rani PJ. 2014. Variability, heritability and genetic advance of yield and yield attributing traits over different environments in sesamum (Sesamum indicum L.). Trends in Biosciences 7 (17): 2402-2404

Sabiel SAI, Ismail MI, Abdalla EA and Osman AA. 2015. Genetic variation in sesame genotypes (Sesamum indicum L.) grown in the semi-arid zone of the sudan. Sabrao Journal of Breeding and Genetics 47 (3): 214-220.
Saxena K and Bisen R. 2016. Genetic variability correlation and path analysis studies for yield and yield component traits in sesamum (Sesamum indicum L.). International Journal of Agriculture Sciences 8 (61): 3487-3489.

Shekhawat RS, Meena SK and Singh B. 2013. Genetic divergence analysis in sesame. Indian Research Journal of Genetics and Biotechnology 5 (2): 105-110.

Tripathi A, Bisen R, Ahirwal RP, Paroha S, Sahu R and Ranganatha ARG. 2013. Study on genetic divergence in sesame (Sesamum indicum L.) germplasm based on morphological and quality traits. Bioscan 8 (4): 1387-1391.

Vanishree L and Goudappagoudar Banakar RR. 2013. Analysis of genetic variability for yield and its components in sesame (Sesamum indicum L.). International Journal of Plant Sciences 8 (1): 91-93.

\section{How to cite this article:}

Atul Singh, Rajani Bisen and Akanksha Tiwari. 2018. Genetic Variability and Character Association in Sesame (Sesamum indicum L.) Genotypes. Int.J.Curr.Microbiol.App.Sci. 7(11): 2407-2415. doi: https://doi.org/10.20546/ijcmas.2018.711.274 